\title{
RELEVANCE OF THE PRODUCTIVE COURSE OF HAIR BEAUTY IN VOCATIONAL HIGH SCHOOLS TO INDUSTRY NEEDS
}

\author{
Ambiyar ${ }^{1}$, Asmar Yulastri $^{2}$, Mimi Yupelmi ${ }^{3}$, Paryono $^{4}$ \\ ${ }^{1,2,3}$ Study Program of Technological and Vocational Education, Universitas Negeri Padang, Indonesia \\ ${ }^{4}$ SEAMEO Regional Centre for Vocational and Technical Education, Brunei Darussalam \\ E-mail: ambiyar@ft.unp.ac.id
}

\begin{abstract}
The problem primarily faced by vocational education institutions is a gap between skills taught at schools and skills required by the industries. This leads to the increasing unemployment rate of Vocational High School graduates. Thus relevant curriculum is required to satisfy the industry demands. This study aimed at analyzing the relevance of the productive course of hair beauty in Vocational High Schools to the job requirements in beauty salons in Padang. This study was qualitative descriptive. The data collection used interviews, observation and documentation. The data collection instruments consisted of observation sheets and interview guidelines. The data were analyzed using the stages of data reduction, presentation and conclusion. The results showed positive relevance of the productive course of hair beauty in Vocational High Schools to the job requirements in beauty salons in Padang. The skills learned in the schools were adequately relevant with the skills required by beauty salons, since from thirteen productive lessons taught in the schools, eleven of them were implemented and used in the workplaces.
\end{abstract}

Keywords: hair beauty, industry needs, productive course, relevance

\section{INTRODUCTION}

The challenges of globalization era demand people to be ready and to give quick response to improve Human Resources. Hendayat (2005) states that human resources generated by the world of education will be the resource that underpins implementation of industrialization in Indonesia, therefore the policies of human resources development must be started with the improvement of the education system that leads to the provision of human resources used in industries. Subsequently, education has the important role to provide high-quality human resources.

Education in schools requires a curriculum. A curriculum that used by Vocational High Schools also known as Sekolah Menengah Kejuruan (SMK) should be relevant with the existing needs in the business world and industrial world, because the curriculum is an important thing in the education and significantly affect the quality of the graduates. Mulyasa (2007) suggests that every educational unit is expected to develop a curriculum that can be implemented in each educational unit. Sumantri (2004) also states that curriculum must be started with the specification of students' needs, because the target of the curriculum is designed based on community's needs, because the community will be the users of the graduates. In addition, Mangkunegaran (2003) explains that education is considered relevant if the results obtained from education are useful for real life. The education which is not relevant with the demands of the world of work will produce the graduates who are hardly able to face the demands of the world of work.

In relation to the relevance of education, relevance is defined as relationship, conformity, connection of the objectives, useful directly with what is needed. Djojonegoro (1995) states that the policy to increase quality and relevance of education, includes four aspects namely curriculums, educational staffs, educational facilities and leadership of educational units. Sadjad (2002) adds that relevance is an important component because relevance is the factor that determines the existence of an educational institution. The educational institutions can be considered 
relevant if the graduates can be quickly absorbed by employment in accordance with the fields and the academic background, either in local, national, or international levels. So that, the curriculum relevance to the industrial world's needs becomes important in order to produce qualified graduates to be employed by the industries.

In relation with vocational education, Wardiman (1998) states that vocational education is a part of an education system that prepares someone to work in the workgroup or a work field from the other work fields. Therefore, the development of curriculum must be directed to prepare students to enter the employment as human resources who are ready to face the free market that demands quality improvement of competitive and productive human resources. This is a challenge for the educational world.

Several problems faced by educational institutions are incompatibility and a gap between skills competency that learned at Vocational High School and the skills need by the world of industries (Marleni, 2014). Moreover, Masriam (2014) suggests that the employers consider that various vocational education efforts are not relevant to their needs. The educational program carried out by vocational education tend to be educationally concept oriented, either in the content of the lessons or in the values contained in the lesson. Learning in the vocational education tends to be efforts to only develop knowledge and theories and ignore the performance which is the key to reach the characteristic of a competency.

The effect of this gap is the low employment rate of Vocational High School graduates by the industries. In August 2008, the Central Bureau of Statistics states that the Open Unemployment Rate is still dominated by senior high school or vocational high school graduates that reaches $17.26 \%$ which is improved from $14.80 \%$ in February 2008. The Deputy of Social Statistics of the Central Bureau of Statistics states that two out of five Vocational High School graduates are categorized as unemployed (Anaf, 2009). Similarly, from all of graduates of SMK N 7 Padang and SMK N 2 Padang from 2013 to 2015 , the percentages of unemployed graduates are $45.61 \%$ and $25.31 \%$ respectively (Public Relations of SMKN 6 Padang and SMKN 7 Padang).

The unemployment is caused by the students who lack skills in working. The evaluation results of vocational education and training, indicate that vocational education and training both in content and in the process does not cover the area of competence optimally (Masriam, 2014). Vocational education hardly capture the essence of a job or is unable to properly integrate the learning process with employment demands. Materials presented to students and their relevance to the needs of the world of work tend to be very rarely concerned. To improve vocational education, this problem must be settled.

Observations and interviews with teachers of Beauty Therapy at SMK N 7 Padang revealed that based on the spectrum of 2008 on the division of subjects to be taught in one semester, there are some subjects that are almost same with the other subjects with too much time allocation, resulting in low competency achievement of the graduates. For example, the subject of hair straightening, in which the lesson of hair straightening and smoothing is separately taught in class XI in 6 hours a week for each subject and in the same semester in class XII the students also study hair straightening in 6 hours a week.

Another problem in SMK Negeri 6 Padang is the subject of hair wash and hair drying which is also separated by the time allocation of 4 hours a week for each subject. These subject should be combined to save time. The remaining time can be used to teach students about the service needed by the community and the industries today such as makeup and Mahendi art to increase knowledge and skills of the students according to the needs of the world of work.

Some complaints from the beauty salon industries such as Meihua Salon and Andri 
Salon which state there are still many graduates who do not know the equipment used in the hair arrangement, lack of psychomotor competence such as hair pruning and coloring. They only know the theory only. Interviews on Martha Siska Salon, Lian Salon and Roni Salon shows that there are graduates who are still hesitant in carrying out the activity of hair straightening and do not understand and master services in beauty salons like hair blow, hair curling. The graduates also do not know other services in beauty salons such as Mahendi and Electric Facials.

Referring to the problems that have been described before, it is necessary to express the relevance of the curriculum applied in schools with the job requirements in beauty salons. Therefore, this study examines the relevance of Vocational High Schools Curriculum to the job requirements of Beauty Salons in Padang.

\section{METHOD}

This study used a qualitative descriptive method. The reason for using the qualitative approach in this study was because the researcher saw the characteristics of the problem that could develop naturally in line with condition and situation of the field. Sudjana (2006) stated that descriptive studies take the problem or the focus on actual problems as it is at the time of the study is carried out. To show the relevance of curriculum to beauty salons' requirements, it was carried out a job analysis in addition to documentation and observation.

The locations of study were SMK N 6 and SMK N 7 Padang. The study was also carried out at six beauty salons where the graduates of SMK N 6 and SMK N 7 Padang that consisted of Meihua Salon \& Bridal, Martha Siska Salon, Andri Salon, Roni Salon, Edri Salon, and Lian Salon.

Data collection techniques were observations, interviews and documentation. In this study, the researcher played the role of a passive participant. Moleong (2011) stated that participant observation technique is the main technique in qualitative studies. The interview was carried out with beauty salon staffs, teachers, graduates who had worked in the beauty salons in Padang. There were six, four and six research informants form industrial staffs or beauty salons, from teachers and from the graduates respectively. The four teachers consisted of two teachers form SMK N 6 and two teachers from of SMK N 7 Padang. There were six research informants form graduates. The interview consisted of 26,21 and 26 questions for beauty salon staffs, teachers, and the graduates respectively. The data was also obtained through observation about the learning process and the performance of the graduates in their workplaces. 13 skills were observed in this observation including (1) hair washing, (2) hair drying, (3) hair and scalp care, (4) hair cutting, (5) hairstyling, (6) hair curling, (7) hairpiece styling, (8) hairstyling, (9) hair bun, (10) traditional hair bun, (11) barber techniques, (12) hair dyeing, and (13) hair straightening. The data was obtained from the curriculum documentation analysis and syllabus.

A technique to check for validity data is triangulation activity toward the source that means to compare and check the degree of believing of information that obtained with other informant and triangulation with theory. Data collected with various technique, and then carried out analysis data. There are 3 steps in qualitative research, are follows: data reduction, presentation of data and draw a conclusion (Moleong, 2006; Sugiyono, 2009; Miles \& Huberman, 2013).

\section{RESULTS AND DISCUSSION}

The skills learned by students at the school correspond with the syllabus in the curriculum of Hair Beauty. There are 13 skills taught through theoretical and practical studies. The students are expected to be careful and not in a hurry in the practices to keep occupational safety and to be responsible for the practice

The productive course of Hair Beauty learned in the school is a vocational basic 
productive program including (1) services, (2) anatomy and physiology, (3) cosmetics, (4) SPA services, and (5) Occupational Health and Safety (OSH). The basic competencies of the course are as follows: (1) hair washing, (2) hair drying, (3) hair and scalp care, (4) hair cutting, (5) hairstyling, (6) hair curling, (7) hairpiece styling, (8) hairstyling, (9) hair bun, (10) traditional hair bun, (11) barber techniques, (12) hair dyeing, and (13) hair straightening.

The problem aroused is that the students lack of confidence in doing certain hair cutting and barber techniques because they have high risks. The schools also do not provide the students with adequate practical equipment that correspond to the development of the industry thus the students are not ready when going to the workplaces. Moreover, the other problem is that some skills are not really used in the workplaces such as traditional bun and hair pieces. These skills are usually only used by beauty salons that provide special makeup and for weddings. The skills are not used in regular beauty salons because the consumers usually go for body care.

To carry out effective and efficient works in the industry, the students or graduates should be equipped with competencies. Competencies derived from the word of competency which is an adjective that means competence, ability, and authority. The adjective of competence is competent that mean competence, can, and agile. Robbin (2007) defines a competency as the ability to carry out a certain job determined by intellectual and physical abilities.

A competency includes (1) how to do a job, (2) how to organize the job, so the job can be accomplished, (3) what should be done if the other things happen that are different with preliminary planning, and (4) how to use the competency to solve the problem or to do the job with different condition. All of these are human characteristic as learning outcomes in the education field.

A competency taught in the school have corresponded with the syllabus in the curriculum of Hair Beauty, although there are still some skills that have been not mastered by students like hair cutting and barber techniques. This happens because of the students' lack of confidence in cutting practices. To increase the students' ability, the students must train and improve their confidence so that they can practice any work.

All of the graduates who enter the workplaces have basic skills to work at a beauty salon, although it still cannot be considered as a professional. There are still many graduates who lack the skills of hair cutting, barber techniques, and styling. To increase the students' ability, it should be started with the students' confidence so that students can do what they must do, and the school should focus more on practical learning than theories.

The competency of the graduates must correspond with the beauty salons' job requirements and to the industry standard. The learning process has corresponded with the industry needs, but in the fact, it still found graduates who cannot comply the industry needs to show professional skills.

Anastasia (2009) explaines that beauty salon business is a business in the field of beauty services and body care to maintain and restore life vitality. Melcalf \& Bijan (2010) adds that a beauty salon is a special place to care the body using beauty equipment and cosmetic materials that are carried out by beauty experts.

Indonesian Ministry of Health (2011) states that service activities in the science of beauty implemented in a beauty salon business can be grouped in four main parts as follows: (a) Skin Care, (b) Makeup, (c) Hair Care and (d) Haircut. Furthermore, Hakim (1999) states that applying beauty skills are associated with hair styling and caring, body caring, and makeup.

Generally, the skills learned by graduates in the school are relevant with the industry's needs, although there are some skills that are less used like hairpiece, traditional bun, so that the skills cannot be applied at the salon, and there are services that must be learned by 
students in the school are hijab and mahendi art. The students' competencies which are not relevant with the industry needs are presented in Table 1.

Table 1. Students' Competencies which Are Not Relevant with the Industry Needs

\begin{tabular}{|c|c|c|}
\hline Competencies & Problems & Industry needs \\
\hline $\begin{array}{l}\text { Traditional } \\
\text { Bun }\end{array}$ & $\begin{array}{l}\text { The industry } \\
\text { provides them } \\
\text { especially for } \\
\text { makeup and } \\
\text { wedding } \\
\text { salons, } \\
\text { costumers } \\
\text { mostly wear } \\
\text { hijab }\end{array}$ & $\begin{array}{c}\text { Competency } \\
\text { of hijab and } \\
\text { mahendi art, } \\
\text { because hijab } \\
\text { and mahendi } \\
\text { art are } \\
\text { required by } \\
\text { the constumers }\end{array}$ \\
\hline $\begin{array}{c}\text { Barber } \\
\text { Techniques }\end{array}$ & $\begin{array}{l}\text { Students still } \\
\text { study basic } \\
\text { and theoretical } \\
\text { materials, it } \\
\text { has a high } \\
\text { risk, } \\
\text { inadequate } \\
\text { tools in the } \\
\text { school }\end{array}$ & $\begin{array}{l}\text { Students } \\
\text { should } \\
\text { understand } \\
\text { about barber } \\
\text { techniques } 1 \\
\text { before going } \\
\text { to industry }\end{array}$ \\
\hline
\end{tabular}

The teachers of Hair Beauty at SMK N 6 Padang and SMK N 7 Padang state that the beauty salons and the graduates that work in the beauty salon say that generally, the skills that learned in the school are relevant with the skills required by beauty salons. Of 13 productive courses taught in the school, 11 courses can be applied and used by the salon staffs. There are just 2 skills that are not used by beauty salons, namely traditional bun and hair pieces. In addition, the graduates lack hair cutting skills which are required by the industry.

Graduates of vocational education are expected to work in an industrial world that corresponds with their skills. Vocational education is education that aims to (1) make ends meet of communities for the labor market, (2) to increase education choice for each individual, and (3) to grow motivation to learn throughout life. Evans \& Edwin (1978) adds that vocational education is a part of an education system that prepares individuals for the job or job groups. Vocational education is all of type and form of learning experiences that help students to carry out their vocational development steps from identification, exploration, orientation, preparation, choosing and making a career in the workforce. It can be said that vocational education is education to enter the workforce and for everyone that needs it. The limits of vocational education show that vocational education is identical with the education of the world of work.

The new graduates can be said competent if they have reached competency standards that determined by the school and the Indonesian National Competency Standards. Perseverance and abilities that had by students become the factor in determining the learning mastery besides normative and adaptive values. Assessments of attitude, knowledge, and skill are put together to see the students can continue to the next step or not. For incompetent students cannot continue to the next competency. To reach the students' competency, they must do their work optimally with or without a teacher. After the students have the competency, the students can ask the teacher to assess them about their competency and declared to be competent by the teacher.

Corresponding with the Regulation of the Indonesian Minister of Health, the students pass the primary and secondary education after accomplishing all learning programs, get minimum values either in the last assessment for all group courses, religion course and good attitude, nationality and personality, aesthetics course group, physical course group, sports, and health, pass the school exam for science and technology and pass the national exam (Ministry of Health, 2011). It means a productive course of Hair Beauty is divided into two namely the productive program and hair vocational competency productive program. The basic vocational productive program consists of (1) services, (2) anatomy and physiology, (3) cosmetics, (4) SPA services, and (5) OSH. The Hair Beauty competency productive program course consisted of (1) hair washing, (2) hair drying, (3) hair and scalp care, (4) hair cutting, (5) hairstyling, (6) hair curling, (7) hairpiece styling, (8) hairstyling, 
(9) hair bun, (10) traditional hair bun, (11) barber techniques, (12) hair dyeing, and (13) hair straightening. Therefore before graduating, all of the competencies must be had by the students.

In addition, the techniques learned in the school are still basic and theoretical. It means that the goals of vocational education have not been achieved maximally. Therefore, the students should be equipped with adequate knowledge and skills to enter the workforce by trainings or practices that correspond to the respective fields. The training is usually carried out in the last semester of grade XI which is also known as Industrial Practices. The partnership between the school and the industry can prepare the students effectively that correspond with industry needs (Baser et al., 2017; Nurmayani et al., 2017).

The journal of SMKN 7 Padang explains that an Industrial Practice is a training that demands quality of skills and competencies systematically and it is programmed between education in the school and the workforce. The implementation of Industrial Practices is conducted with certain procedures. The students are required to have the basic skills of the field before entering the workforce.

The goal of Industrial Practices is to add knowledge obtained in the workforce and can apply knowledge from the learning process in schools in the real world of work. But in the fact, the students who passed the program cannot apply the skills in the work world to satisfy the industrial demands. Therefore, the students must be trained completely during the Industrial Practices to increase the students' ability. The location of Industrial Practices must be determined by the school appropriately so that the students can get the high quality industries to knowledge and experiences. The industrial staffs also can involve the students in doing the job at the beauty salon.

The occurrence of a paradox in this study is caused by the results of a preliminary observation in which the researcher obtained data from two beauty salons and interviews the staffs. On the data of the study, the researcher carried out the interviews to the directors of 6 beauty salons in Padang city, so that the results obtained were different with the preliminary observation.

\section{CONCLUSION}

The productive course of Hair Beauty learned by students in the school has corresponded with a syllabus in the curriculum of Beauty Therapy that teaches thirteen skills of the vocational basic productive program including theoretical and practical learning as well as character education. The students are expected to demonstrate occupational health and safety and be responsible for the practices. The graduates' competency required by beauty salons in Padang city is generally corresponded with the needs of the industry. Of thirteen productive courses taught in the school, eleven courses can be applied and used in the workplaces. However, there are 2 skills that less and not used namely traditional local bun and hairpieces. On the other hand, the skill that is not mastered by the students but is required by the industry is hair cutting. The school should be more concerned about students' needs in the learning mainly in practical learning. The practical equipment and materials should cope with the development of the industry. The teachers should improve the students' practical skills, so that they can be more competent in the industries, and the teachers should know the development of industrial worlds, to give the new knowledge to students. The industries should give recommendations as evaluation and feedbacks for the school and work collaboratively with the school to produce skilled middle-level workforce that satisfies the industry needs.

\section{REFERENCES}

Anaf. 2009. Badan Pusat Statistik. Jakarta

Anastasia, H. 2009. Cantik, Sehat dan Sukses Berbisnis Spa. Yogyakarta: Kanisius 
Baser, J.A., Mat Jizat, N., Yunus, F.N., Rahim, M.B., Abdul Razzaq, A. R., Hasan, A. 2017. Competency of National Dual Training System Industry Advisors. Jurnal Pendidikan Teknologi dan Kejuruan.. 23. 4, 328-338.

Djojonegoro, W. 1995. Peningkatan Kualitas Sumber Daya Manusia untuk Pembangunan. Jakarta: Depdikbud

Evans, R. N. \& Edwin, L.H. 1978. Foundation of Vocational Education. Columbus, Ohio: Charles E. Merrill Publishing Company

Finch, C.R. \& Crunkilton, J.R. 1999. Curriculum Development in Vocational and Technical Education: Planning, Content, and Implementation. Sidney: Allyn and Bacon

Hakim, N. 1999. Pengetahuan Tata Kecantikan Tingkat Terampil. Jakarta: Indonesian Department of Education and Culture

Hendayat, S. 2005. Pendidikan dan Pembelajaran Teori, Permasalahan dan Peraktek. Malang: Penerbit Universitas Muhhamadyah Malang

Mangkunegaran, A.P. 2003. Perencanaan dan Pengembangan Sumber Daya Manusia. Bandung: PT Refika Aditama

Marleni. 2014. Implementasi Keterampilan Lulusan Program Keahlian Tata Kecantikan SMK Negeri 6 Padang Dalam Bekerja Pada Industri Salon Kecantikan Berklasifikasi Utama. Thesis. Unpublished. Universitas Negeri Padang

Masriam, Bukit. 2014. Strategi dan Inovasi Pendidikan Kejuruan. Bandung: Alfabeta

Melcalf, S. \& Bijan, YZ. 2010. Berani Memulai dan Menjalankan Bisnis Salon Kecantikan. Jakarta: PT Tiga Serangkai
Miles, M.B. \& Huberman, A. M. 2009. Qualitative Data Analysis. Translator: Tjetjep Rohendi Rohidi. Jakarta: UI Press

Ministry of Health. 2011. Peraturan Direktur Jenderal Bina Gizi dan Kesehatan Ibu dan Anak Nomor HK. 01. 01/ B1.4/4051/2011 tentang Pedoman Penyelenggaraan Salon Kecantikan di Bidang Kesehatan yang diterbitkan. Jakarta: Ministry of Health of Indonesia

Moleong, J. L. 2005. Metodologi Penelitian Kualitatif. Edisi Revisi. Bandung: Remaja Rosdakarya

Mulyasa, E. 2007. Menjadi Guru Profesional Menciptakan Pembelajaran Kreatif dan Menyenangkan. Bandung: Rosda Karya

Nurmayani, S., Sugiarti, Y., \& Mujdalipah, S. 2017. Application of a Blended Learning Model in Agricultural Vocational High School. Jurnal Pendidikan Teknologi dan Kejuruan. 23. 4, 355-361

Sadjad, R.S. 2002. Paradigma Baru Pendidikan Tinggi untuk Menciptakan Sumber Daya Manusia Unggulan. Makasar: UM

Sudjana, N. 2004. Penelitian dan Penilaian Pendidikan. Bandung: Sinar Baru Algesindo

Sugiyono. 2009. Metode Penelitian Kuantitatif, Kualitatif dan $R \& D$. Bandung: Alfabeta

Sumantri. 2004. Life Skill yang tidak Terpisahkan dari Kurikulum. Konvensi Nasional Pendidikan Indonesia $V$ 